\title{
Osiedle Czechów Południowy. Analiza prac konkursowych SARP i rozwiązań przyjętych do realizacji
}

\author{
Michał Dmitruk \\ https://orcid.org/0000-0002-6368-4206 \\ m.dmitruk@pollub.pl \\ Katedra Architektury, Urbanistyki i Planowania Przestrzennego, \\ Wydziat Budownictwa i Architektury, Politechnika Lubelska
}

\begin{abstract}
Streszczenie: Duże osiedle mieszkaniowe na wzgórzach po północnej stronie rzeki Czechówki planowane było już w latach 50-tych XX wieku. Pod intensywną zabudowę wielorodzinną przeznaczono tereny wsi: Czechówka Górna i po części Bielszczyzna. W 1965 roku Lubelski oddział SARP ogłosił konkurs zamknięty na opracowanie koncepcji zagospodarowania wspomnianego obszaru. Zgłoszone prace prezentowały innowacyjne, niekiedy radykalne podejście do urbanistyki nowoczesnego osiedla wielorodzinnego, które w wybranych przypadkach dały podstawy do opracowania Ogólnych Planów Zagospodarowania badanego terenu. Analiza rozwiązań proponowanych w pracach konkursowych, jak i również porównanie ze stanem istniejącym dostarczyć mogą ważnych informacji o rozwoju lubelskiej myśli urbanistycznej w okresie PRL.
\end{abstract}

Słowa kluczowe: osiedle, urbanistyka, zabudowa wielorodzinna, konkurs SARP, mieszkalnictwo, PRL

\section{Wprowadzenie}

Dzielnica Czechów (Północny i Południowy) jest to silnie zurbanizowany obszar miasta Lublina, o dominującej mieszkaniowej-wielorodzinnej funkcji zabudowy, łącznie zamieszkały przez około 40000 mieszkańców ${ }^{1}$. Tereny na których zlokalizowane jest osiedle leżą na historycznych gruntach ziemskich i folwarcznych, funkcjonujących dawniej jako: Bielszczyzna, Lemszczyzna, Czechówka Górna, Czechów Górny oraz Czechów Dolny². W $1916^{3}$ roku część terenów Czechowa została przyłączona do granic administracyjnych Lublina, z kolei wsie w obrębie dzisiejszej dzielnicy włączone zostały w granice miasta na mocy decyzji Miejskiej Rady Narodowej z 1957 roku, co stanowiło pierwszy krok formalny do realizacji na wspomnianym terenie zabudowy mieszkaniowej. Obszar ten posiadał pierwotnie funkcję głównie rolniczą, z niewielkimi skupiskami zabudowy w typie wiejskim. Dopiero w latach 70-tych XX wieku nastąpił jego dynamiczny rozwój i intensywna zabudowa.

Istotnym czynnikiem wpływającym na kierunki rozwoju miasta, jak i również przyszłego osiedla, była krytyka niekontrolowanego rozwoju, wynikłego z realizacji pobieżnych założeń zawartych w planie sześciolet$\mathrm{nim}^{4}$. W celu sprecyzowania kierunku rozwoju Lublina, podjęto w 1956 roku kroki w celu opracowania planu

2 Przesmycka N., Dzielnica Czechów w Lublinie - geneza układu urbanistycznego, [w:] TEKA Komisji Architektury, Urbanistyki i Studiów Krajobrazowych, Oddział Lubelski PAN, 3/2015. Szerzej historię uwarunkowań rozwoju przestrzennego Lublina (w tym terenów Czechowa), autorka opisuje w swojej monografii: Lublin - Przeobrażenia urbanistyczne 1815-1939. Politechnika Lubelska, 2012

3 za: Stownik Geograficzny, t. I, Warszawa 1880, s. 216.

4 Ustawa z dnia 21 lipca 1950 r. o 6-letnim planie rozwoju gospodarczego i budowy podstaw socjalizmu na lata 1950-1955. Dz.U. z 1950 r. nr 37, poz. 344 
zagospodarowania przestrzennego ${ }^{5}$.W 1959 została przyjęta finalna wersja Ogólnego Planu Zagospodarowania Przestrzennego Miasta Lublina który przeznaczał tereny dzisiejszego Czechowa pod zabudowę wielorodzinną. ${ }^{6}$ Założenia sformułowane we wspomnianym planie (szczególnie etap na rok 1965 i etap perspektywiczny 1980) dały podstawy do określenia wytycznych formalnych dla konkursu nr 424 SARP z 1965 roku, na projekt dzielnicy Czechów. Z kolei opracowania konkursowe okazały się przydatne w sformułowaniu wytycznych kolejnego Ogólnego Planu Zagospodarowania Przestrzennego miasta Lublina z 1969 roku, a także Planu Szczegółowego, który w sposób ścisły określał zakres inwestycji i zasady realizacji zabudowy na Czechowie.

Analiza opracowań konkursowych, założeń planistycznych i ostatecznie zrealizowanych projektów urbanistycznych, dostarcza informacji o wieloletnim procesie kształtowania się jednej z największych Lubelskich dzielnic. Porównanie pomoże również określić które rozwiązania projektowe uznano za najtrafniejsze i przeznaczone do realizacji a także jak funkcjonują one 40 lat od ich powstania.

\section{Konkurs SARP}

W 1965 roku Lubelski Oddział SARP zgłosił do Prezydium Miejskiej Rady Narodowej chęć organizacji konkursu na projekt urbanistyczny zabudowy wielorodzinnej zlokalizowanej na terenie Czechowa ${ }^{7}$. Funkcję sekretarza organizacyjnego konkursu przejął architekt Kazimierz Majewski, a sędziego referenta architekt Zdzisław Wośko. Konkurs został ogłoszony 9 września 1965 roku i otrzymał numer referencyjny 424. Miał on charakter zamknięty, w związku z czym wytypowano 8 jednostek projektowych z różnych miast Polski ${ }^{8}$ (w tym trzy z Lublina), którym wysłano zaproszenie do udziału w opracowaniu planów konkursowych.

Teren opracowania obejmował ok. 250 hektarów powierzchni. Zamykać miał się w obszarze na południe od planowanej drugiej obwodnicy Lublina (0-167-KP) i na wschód od ówczesnego poligonu wojskowego na tzw. Górkach Czechowskich. W związku z brakiem określenia jednoznacznych granic opracowania projektowego, poszczególne zgłoszone prace różnią się od siebie pod tym względem. W zakres opracowania konkursowego wchodzić miały:

- Plansza orientacyjna w skali 1:5000, z naniesieniem elementów kompozycyjnych dzielnicy, - Plansza podstawowa w skali 1:2000, zawierająca podział dzielnicy na jednostki strukturalne, umożliwiające etapowanie inwestycji, linie rozgraniczające tereny o odmiennym przeznaczeniu, linie zabudowy, układ i klasę prowadzonych ulic, rozmieszczenie przystanków komunikacji miejskiej, układ głównych ciągów pieszych i układ zieleni

- Plansza kompozycyjna w skali 1:2000, zawierająca linie rozgraniczające tereny o odmiennym przeznaczeniu, zarysy poziome budynków a także ich wysokość i funkcję, plan dojazdów i ciągów pieszych, ulice, drogi, place, układ przystanków, tereny zielone a także wytyczne ukształtowania terenu, wraz z rzędnymi.

- Plansza kompozycyjna w skali 1:1000, pokazująca rozmieszczenie placów zabaw, elementów małej architektury, kiosków „Ruchu” a także innych elementów uznanych przez architektów za istotne.

- Plansza ideogramowa uzbrojenia terenu w instalacje techniczne - skala 1:2000

- Plansza ukazująca etapowanie inwestycji w skali 1:2000, wykonana na kalce w oparciu o plansze podstawową

- Projekty rozwiązań funkcjonalnych rzutów budynków lub sekcji na kalce technicznej w formacie nie większym niż A3 w odrębnej teczce.

- Makieta założenia w skali 1:2000

- Opis wyjaśniający przyjętą koncepcję.

Opracowanie miało być wykonane techniką trwałą, z przyjętymi oznaczeniami zgodnymi z instrukcją zawartą w okólniku nr 10 Przewodniczącego KBUA z dnia 14.12.1962 roku. Uczestnikom dostarczono odpowiednie podkłady geodezyjne, wraz z warunkami fizjograficznymi, jak i również warunki konkursowe, które należało

5 Furgał E., Ogólny plan zagospodarowania przestrzennego m. Lublina z 1959 roku, [w:] Lubelska Pracownia Urbanistyczna 1955-2005, Lublin 2005.

6 Założenia planu szerzej opisane w: Pastuszko I., Plany urbanistyczne Lublina z lat pięćdziesiątych XX wieku: nowa ideologia czy przedwojenna kontynuacja, Rocznik Lubelski 43, 2017, s. 216

7 Majewski K., Dzielnica mieszkaniowa Czechów w Lublinie. Konkurs zamknięty SARP nr 424, Architektura, 10 (287)/1971

8 Kraków, Wrocław, Warszawa Katowice, Wybrzeże, oraz Lublin. 
uwzględnić w opracowaniach do dnia 1 października 1968 roku. We wspomnianych warunkach określono planowaną ilość mieszkańców na 40000 (z marginesem max. 10\%), nie określono natomiast szczegółowo rodzaju, wielkości, ani wysokości poszczególnych budynków mieszkaniowych. Można zakładać iż preferowano budynki średniowysokie i wysokie, (choć nie sformułowano tego jednoznacznie) gdyż zawarto zapis, ze względu na konfigurację terenu, dopuszcza się zabudowę mieszkaniową 2 lub 3 kondygnacyjną. ${ }^{9}$ Określono natomiast metraż mieszkania przypadający na 1 osobę, wynoszący $22 \mathrm{~m}^{2}$, co w momencie obowiązywania normatywu z 1959 roku było współczynnikiem bardzo wysokim. ${ }^{10}$ Zwrócono również uwagę na potrzeby osób starszych, którzy mieli stanowić 30\% populacji dzielnicy. Nakazano również pełną adaptację osiedla domów jednorodzinnych TOR, przy ul. Partyzantów i włączenie zarówno jego, jak i ewentualnych projektowanych obszarów zabudowy jednorodzinnej w system organizacyjno-funkcjonalny całego osiedla. Określono podstawowe współczynniki urbanistyczne, odnoszące się do funkcji oświatowej i usługowo-handlowej. Przyjęto iż 15-20\% określonej grupy dwulatków będzie korzystać ze żłobków (ok. 400-460 dzieci), 60-70 \% dzieci w wieku przedszkolnym będzie korzystać z odpowiednich placówek opiekuńczych (1700-2000 dzieci), a perspektywicznie 106\% dzieci w wieku szkolnym będzie uczęszczać do osiedlowych szkół podstawowych (ok. 5800 dzieci). Lokale handlu detalicznego stanowić miały na każde 1000 mieszkańców $230 \mathrm{~m}^{2}$, lokale usług rzemieślniczych $190 \mathrm{~m}^{2}$ a zakłady gastronomiczne $40 \mathrm{~m}^{2}$. Ponadto planowano lokalizację rejonowej przychodni (jednej na każde 5-10 tys. mieszkańców), osiedlowych domów kultury (jednego na każde 8-10 tys. mieszkańców), filii biblioteki publicznej (30 m²/1000 mieszkańców), lokali dla działalności administracyjnej i społeczno-kulturalnej, warsztatów remontowych jak i terenów zieleni publicznej. Postulowano lokalizację usług w dzielnicowych ośrodkach handlowych, domach towarowych o pow. ok. $3500 \mathrm{~m}^{2}$ i mniejszych pawilonach po ok 350-500 $\mathrm{m}^{2}$.

Program funkcjonalny dzielnicowego ośrodka handlowo-usługowego, określony w wytycznych konkursowych był precyzyjny na tyle, żeby umożliwić szczegółowe zaplanowanie koncepcyjnych pawilonów, wraz z otoczeniem. Określono następujące zapotrzebowanie:

n w dziedzinie usług i handlu na: targowisko miejskie, zakłady gastronomiczne (restauracje, kawiarnie i towarzyszące funkcjom kulturalnym), zakłady rzemiosła, dom mody, zakłady naprawy i konserwacji maszyn, pralnie chemiczne;

- w dziedzinie kultury: domu kultury, kino, biblioteka, klub prasy i książki;

n w dziedzinie opieki zdrowotnej: obwodowa przychodnia z poradnią geriatryczną, szpital miejski, apteki;

- w dziedzinie oświaty: liceum ogólnokształcące, dom dziecka, żłobki, przedszkola, szkoły podstawowe;

n w dziedzinie administracyjnej: biuro Dzielnicowej Rady Narodowej, biura dzielnicowych organizacji politycznych i społecznych, komenda policji, biuro Spółdzielni Budownictwa Mieszkaniowego.

Ponadto przewidziano w obrębie planowanego osiedla hotel na 200 miejsc, biura podróży, urzędy pocztowe, zakład konserwacji sieci telefonicznej, szalety publiczne, zakłady remontowo budowlane i inne. Do każdej wymienionej funkcji określono precyzyjnie współczynnik powierzchniowy, w zależności od wielkości jednostek osiedlowych i planowanych etapów realizacji.

Określono również szczegółowo wytyczne komunikacyjne, jak i również lokalizację planowanej północnej obwodnicy Lublina. Opisano sposób przyłączenia ośrodków dzielnicowych z drogami obwodowymi, jak i również sposób skomunikowania budynków z siecią drogową (kładąc duży nacisk na wyprowadzenie ruchu kołowego na zewnątrz przestrzeni osiedlowych. Zwrócono szczegółową uwagę na powiązanie osiedla w skali miasta, szczególnie z sąsiednimi dzielnicami: Kalinowszczyzna (mieszkaniowa) i Wieniawa (mieszkaniowo-akademicka) a także Śródmieściem i planowanym centralnym ośrodkiem usługowym wzdłuż rzeki Czechówki, jak i funkcją handlową zlokalizowaną wzdłuż osi ul. Lubartowskiej. Określono również współczynniki ilości miejsc postojowych dla samochodów, zarówno dla budynków mieszkalnych jak i usługowych. ${ }^{11}$

9 Warunki Konkursu Zamkniętego SARP, nr 424 na opracowanie koncepcji projektu planu szczegółowego zagospodarowania przestrzennego dzielnicy mieszkaniowej Czechów w Lublinie, s. 3

10 W Normatywie przewidziano iż $11 \mathrm{~m}^{2}$ powierzchni mieszkania, przypadających na jedną osobę, jest to optymalny współczynnik. Za: Uchwała nr 364 Rady Ministrów z 20 sierpnia 1959 r. w sprawie zatwierdzenia normatywów projektowania dla budownictwa mieszkaniowego, MP 1959, nr 81, poz. 422

11 Planowane w wytycznych konkursowych współczynniki miejsc postojowych były wyjątkowo niskie: 130 stanowisk na 1000 mieszkańców, dla budownictwa wielorodzinnego i 15 miejsc postojowych na każde $1000 \mathrm{~m}^{2}$ powierzchni użytkowej w poszczególnych funkcjach usługowych Za: Warunki Konkursu Zamkniętego SARP, nr 424 na opracowanie koncepcji projektu planu szczegółowego zagospodarowania przestrzennego dzielnicy mieszkaniowej Czechów w Lublinie, s. 12 
Istotny nacisk położono na zaplanowanie i organizację terenów zielonych i przestrzeni sportu i rekreacji. Nakazano zabezpieczyć tereny pod osiedlowe parki, zieleń międzyblokową, ogród jordanowski (min. 1,5 ha), zespoły boisk sportowych, międzydzielnicowy ośrodek sportu (14 ha) jak i również ogrodnictwo usługowe i ogródki robotnicze.

Dla wiadomości uczestników konkursu, spoza Lublina, przedstawiono opis uwarunkować przestrzennych terenu, wraz z charakterystyką powiązań w skali miasta i jego głównymi ośrodkami mieszkalnymi, edukacyjnymi, administracyjnymi i głównymi zakładami pracy w mieście. Zwrócono również uwagę na charakterystyczną, pagórkowatą rzeźbę terenu przeznaczonego pod opracowanie projektowe.

Termin składania pracy wyznaczony został na dzień 10 marca 1969 roku, czyli niespełna pół roku, po otrzymaniu materiałów będących podstawą opracowania. W czerwcu 1969 roku rozstrzygnięto konkurs na projekt zabudowy dzielnicy Czechów. W skład zespołu sędziowskiego wchodziło 13-stu architektów, urbanistów i inżynierów budownictwa, zarówno z Lublina, jak i innych miast Polski. ${ }^{12}$ Zdecydowano się nie przyznawać pierwszej nagrody, przyznano natomiast 1, 2 i 3-cie wyróżnienie. ${ }^{13}$ Jak pisze Natalia Przesmycka: „Za najlepiej spetniającą założenia konkursu uznano pracę $n r 2^{14}$ [...] Pracę opisano jako trafnie rozwijającą decyzje planu ogólnego. Podkreślano czytelny układ tras komunikacyjnych i ciągów pieszych, bardzo dobrą lokalizację i ekspozycję ośrodka usługowego. Prawidłowy i zharmonizowany z warunkami naturalnymi podział na jednostki przestrzenne o wyraźnym indywidualnym charakterze. Układ zabudowy podkreśla zarówno walory krajobrazu jak i strukturę dzielnicy. ${ }^{15}$ (Ryc. 1.) Drugie wyróżnienie otrzymał zespół z Lublina - autorzy pracy $\mathrm{nr} 5^{16} \mathrm{z}$ a trzecie miejsce ex aequo Lubelsko-Warszawski zespół - autorzy pracy $n r 7^{17}$ i zespół z SARP Wybrzeże - autorzy pracy nr $3^{18}$

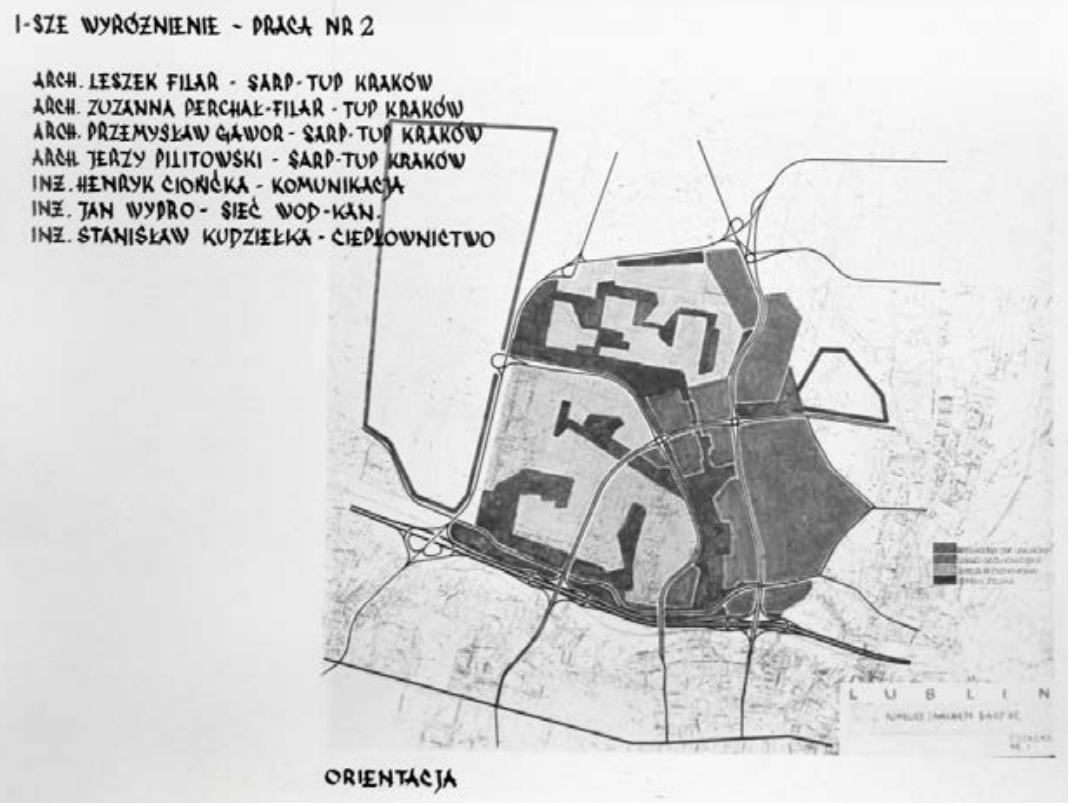

Ryc. 1. Plansza orientacyjna pracy konkursowej $\mathrm{nr} 2$ - I wyróżnienie. Źródło: Archiwum Wydziału Planowania UM w Lublinie - zdjęcie: Michał Dmitruk

12 arch. Stanisław Bukowski, mgr Zygmunt Budziński, arch. Aleksander Dobrowolski, arch. Władysław Hurko, arch. Zbigniew Kramarz, arch. Jacek Nowicki, arch. Olgierd Olszewski, arch. Pacierkowski, mgr Stanisław Pasek, inż. Antoni Samorek, mgr Halina Wiśniewska, mgr inż. Wojciech Wojtysiak i arch. Zdzisław Wośko.

13 Wójcikowski G., Wójcikowski W., Kronika 1944 - 1989, [w:] red. Kruszyńska J., Lublin. Dzieje miasta t. II: XIX i XX w., Lublin 2000.

14 Zespół autorski z Krakowa - architekci: Leszek Filar, Zuzanna Perchal-Filar, Czesław Gawor, Jerzy Pilitowski, komunikacja: inż. Henryk Ciońćka, uzbrojenie terenu: inżynierowie Jan Wydro i Stanisław Kudziełka.

15 Przesmycka N., Dzielnica Czechów w Lublinie - geneza układu urbanistycznego, [w:] TEKA Komisji Architektury, Urbanistyki i Studiów Krajobrazowych, Oddział Lubelski PAN, 3/2015

16 mgr inż. Jan Adamczyk, arch. Janusz Gągała, arch. Janusz Makowiecki, mgr inż. Czesław Chodorowski, inż. Tadeusz Sierzpowski i techn. Wojciech Stankiewicz.

17 Arch. Jerzy Androsiuk, arch. Stanisław Fijałkowski, arch. Rita Nowakowska, arch. Tadeusz Nowakowski, mgr inż. Zdzisław Lechus i arch. Leonard Tomaszewski.

18 arch. Szczepan Baum, arch. Andrzej Jagodziński, arch. Stefan Philipp, mgr inż. Eugeniusz Kołdoń i techn. Grzegorz Kuszel. 


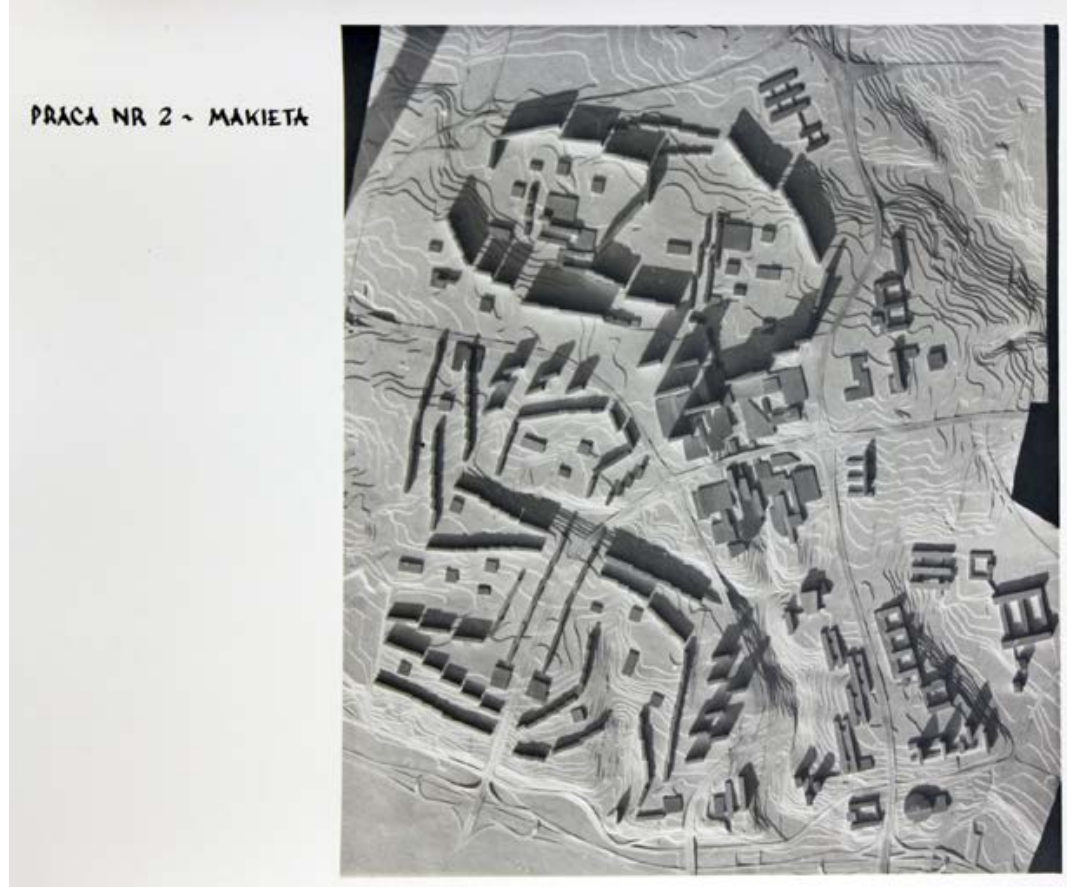

Ryc. 2. Model do pracy konkursowej nr 2 - I wyróżnienie.

Źródło: Archiwum Wydziału Planowania UM w Lublinie - zdjęcie: Michał Dmitruk

\section{Założenia zgłoszonych prac}

Analizując założenia planistyczne zaproponowane w pracach konkursowych zaobserwować można że różnią się one w sposób wyraźny podejściem do kształtowania układów osiedli, jak i siecią ulic i zajmowanym obszarem. Wynika to z faktu iż nowoczesna myśl urbanistyczna dopiero kształtowała się w Polsce po upadku nurtu socrealistycznego w 1956 roku $^{19}$, a większość realizowanych założeń urbanistycznych miała charakter niejako eksperymentalny. Brak ściśle wyznaczonych granic opracowania, jak i również układu infrastruktury drogowej powodował również odmienne kształtowanie się układów osiedlowych. Zaobserwować można że spośród złożonych prac, jedynie opracowanie $\mathrm{nr}$ 2, 5 i 8 dostosowane jest do planowanego w tamtym okresie (obecnie zrealizowanego) układu ulic dzielnicowych. Można zakładać iż autorzy nie otrzymali, bądź nie występowali o odpowiednią dokumentację, bądź plany infrastrukturalne miasta zostały pominięte celowo w opracowaniach, jako nieodpowiadające koncepcji projektowej. Praca nr 2, nagrodzona pierwszym wyróżnieniem, przedstawia wyraźny podział dzielnicy na osiedla, zgodnie z planowanym układem drogowym. W opracowaniu wyraźny jest układ budynków izolujący wnętrza urbanistyczne od głównych dróg, tworząc wewnątrzosiedlowe przestrzenie publiczne.

We wspomnianych obszarach znajdują się zarówno tereny zielone, jak i pawilony usługowe i budynki oświaty, kreując tym sposobem przestrzeń integracji sąsiedzkiej.

Skala zaprojektowanych budynków jest zróżnicowana, przechodząc w sposób płynny od zabudowy niższej na obrzeżach dzielnicy, do budynków wysokich w jej wewnętrznej części - stanowiących dominantę krajobrazową i urozmaicających sylwetę widokową osiedla. 

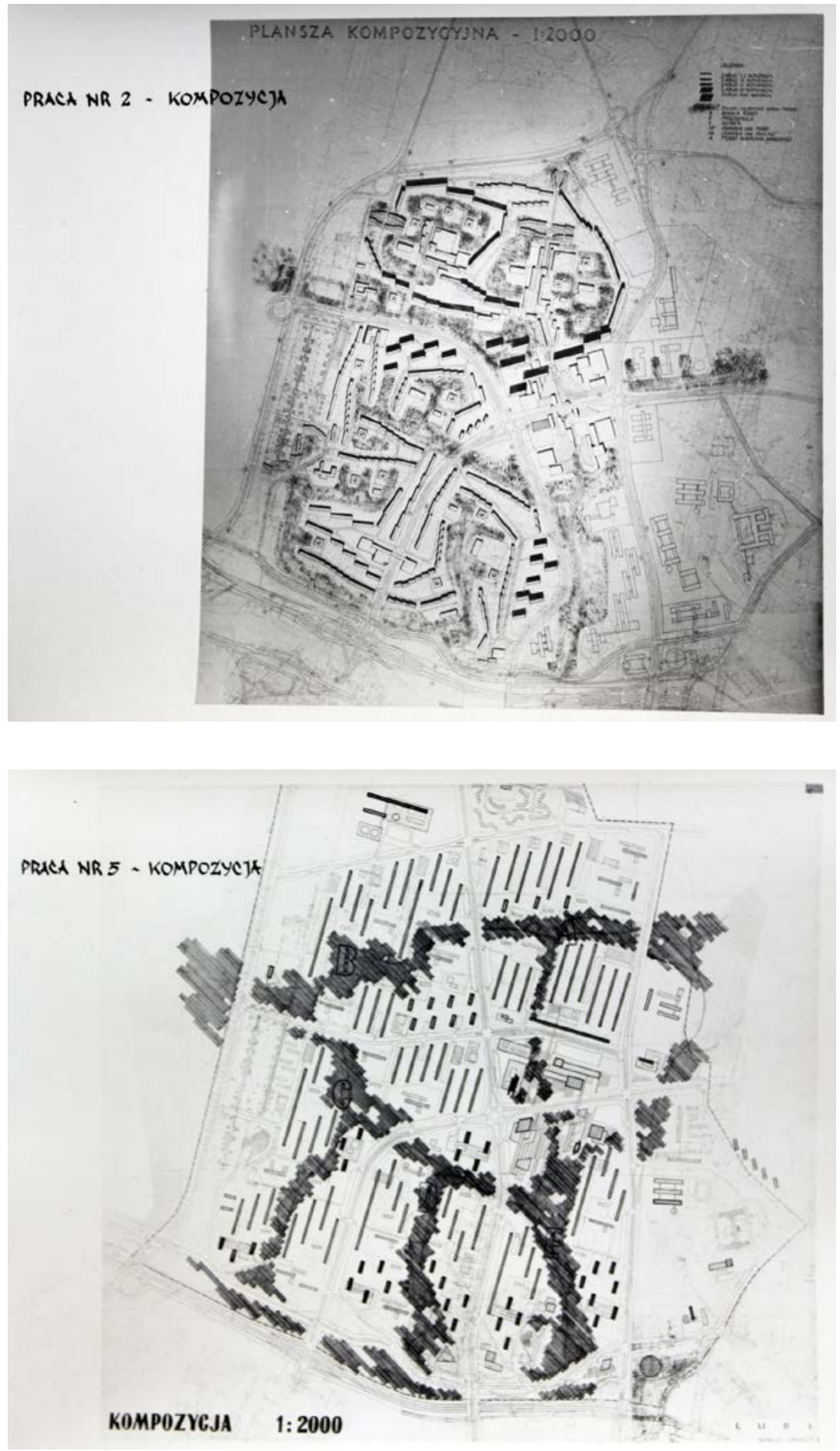

Ryc. 3. Plansza kompozycyjna pracy konkursowej nr 2 - I wyróżnienie.

Źródło: Archiwum Wydziału Planowania UM w Lublinie - zdjęcie: Michał Dmitruk
Ryc. 4. Plansza kompozycyjna pracy konkursowej nr 5 - II wyróżnienie.

Źródło: Archiwum Wydziału Planowania UM w Lublinie - zdjęcie: Michał Dmitruk

Praca nr 5, nagrodzona wyróżnieniem II stopnia, przedstawia układ prostych, równolegle ustawionych względem siebie budynków, w dość ciasnym i nieco monotonnym układzie. Każde z zaprojektowanych osiedli w dzielnicy składa się zarówno z podłużnych, niższych budynków, jak i również zespołu wysokich punktowców, stanowiących osiedlowe dominanty. Budynki nie tworzą wewnątrzosiedlowych stref rekreacyjnych, a ich układ 
bardziej podporządkowany jest geometrii, niż rzeczywistej topografii obszaru. ${ }^{20}$ Zdecydowaną zaletą projektu, na którą jurorzy zwrócili uwage, jest wykorzystanie naturalnych suchych dolin rzecznych w celu stworzenia dużych dzielnicowych terenów rekreacyjnych, łączących ze sobą poszczególne osiedla. Duży ośrodek dzielnicowy, zlokalizowany jest w centralnej części obszaru opracowania, obsługujący całość założenia. Równomiernie rozproszona po terenie dzielnicy jest natomiast funkcja oświatowa, jak i mniejsze pawilony handlowe.

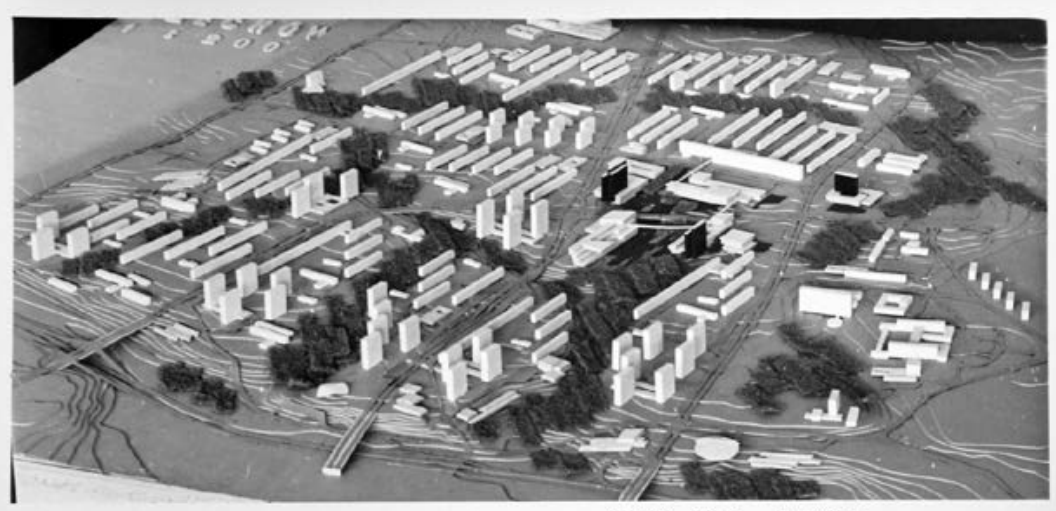

PRACX NR 5 - MAKIETA
Ryc. 5. Model do pracy konkursowej nr 5 - II wyróżnienie.

Źródło: Archiwum Wydziału Planowania UM w Lublinie - zdjęcie: Michał Dmitruk

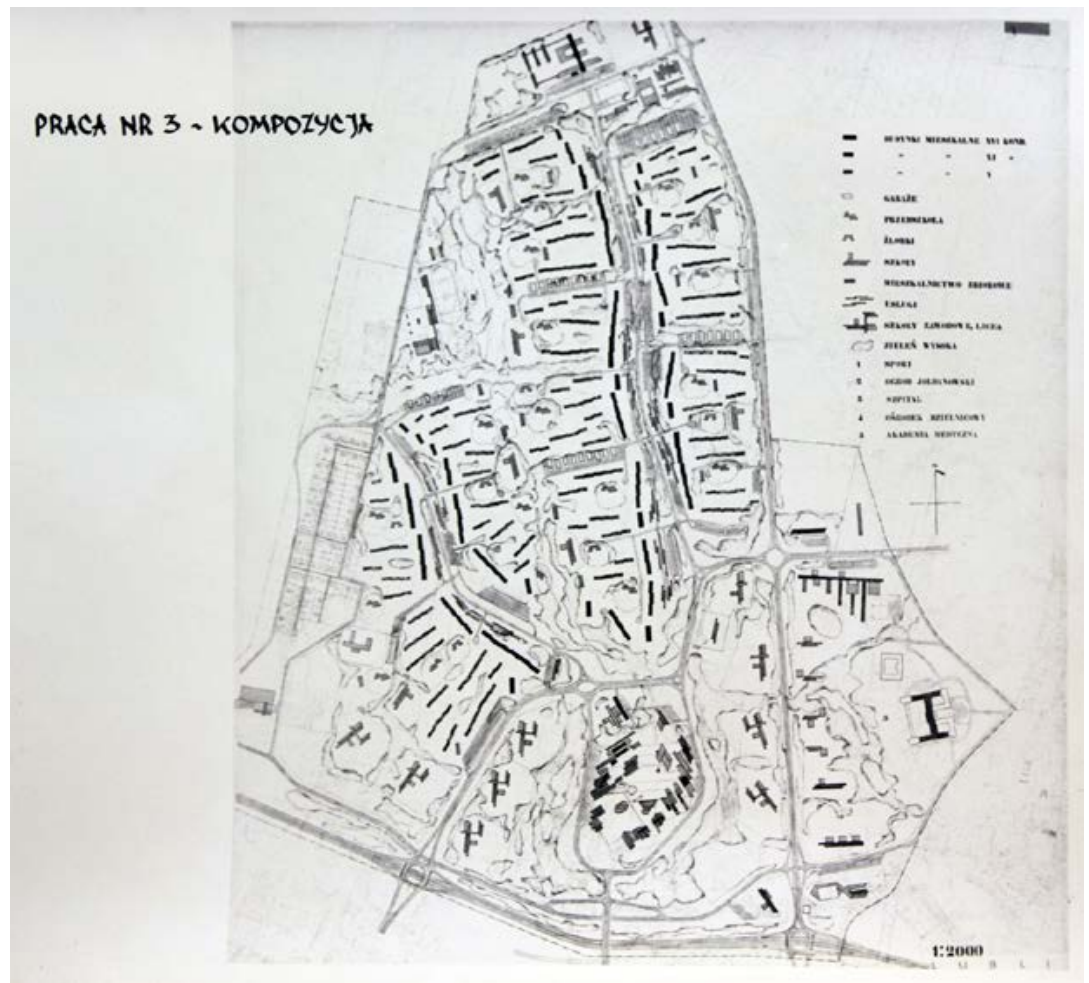

Ryc. 6. Plansza kompozycyjna pracy konkursowej nr 3 - III wyróżnienie.

Źródło: Archiwum Wydziału Planowania UM w Lublinie - zdjęcie: Michał Dmitruk

Praca $\mathrm{nr}$ 3, nagrodzona wyróżnieniem 3-go stopnia ${ }^{21}$ proponowała podział dzielnicy na znacznie mniejsze jednostki osiedleńcze, złożone z kilku podłużnych budynków, przedzielonych strefami parkingowymi i drogami obsługującymi. Charakterystycznym elementem pracy są osie utworzone wzdłuż głównych ulic i umiejscowionych równolegle do nich rzędów budynków, tworzących swoistego rodzaju pierzeję (ulicę miejską), jak i również 
izolujących wnętrza urbanistyczne od najintensywniejszego ruchu kołowego. Dzielnicowe centrum komercyjne umiejscowione jest w południowej części osiedla w dużej odległości od zabudowań mieszkalnych na północy. Kontrowersyjnym rozwiązaniem jest również lokalizacja tak znacznej ilości budynków oświatowych po południowej stronie osiedla ${ }^{22}$. llość ta wykracza znacząco ponad wskazania określone w warunkach konkursowych, a dystrybucja budynków w obszarze dzielnicy zdaje się również nie służyć sprawnemu ich funkcjonowaniu. Na makiecie wycofano się jednak z pokazywania wspomnianych budynków, więc być może było to rozwiązanie wariantowe, scharakteryzowane dokładniej w opisie pracy.

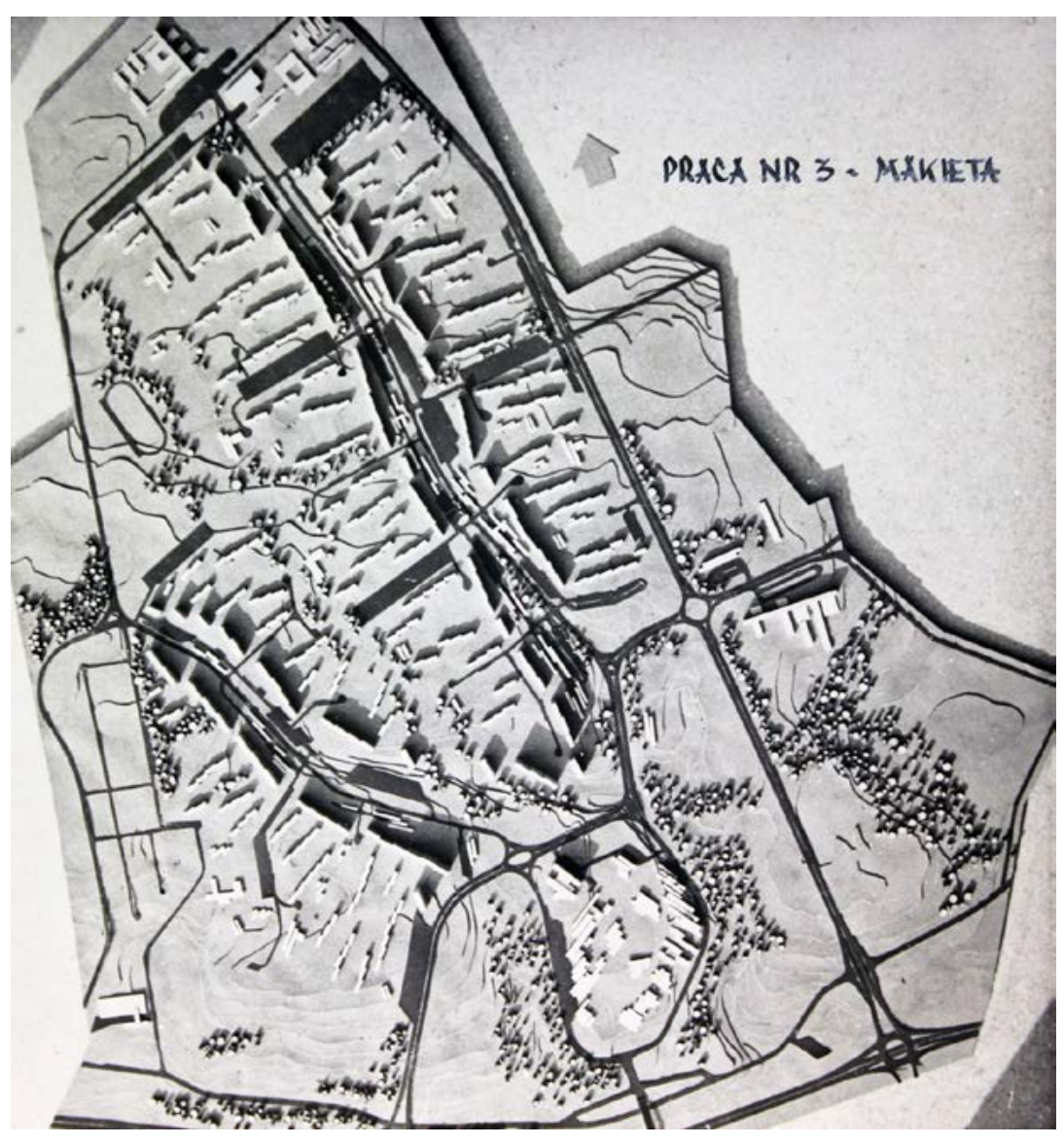

Ryc. 7. Model do pracy konkursowej nr 3 - III wyróżnienie.

Źródło: Archiwum Wydziału Planowania UM w Lublinie - zdjęcie: Michał Dmitruk

Praca $\mathrm{nr}$ 7, nagrodzona wyróżnieniem 3-go stopnia ${ }^{23}$ proponuje wyraźny podział dzielnicy na 5 osiedli. Charakterystycznym elementem są jednak zespoły zabudowy, złożone z niskich, podłużnych budynków, ukształtowanych w kształt księżyca, i towarzyszące im mniejsze budynki domykające wnętrza urbanistyczne, jak i również (przeważnie) dwa punktowce, różnicujące lokalnie typ zabudowy. Projekt tworzy kameralne przestrzenie międzyblokowe, odizolowane od ruchu kołowego za pomocą podłużnych budynków, jednocześnie połączone ze sobą w układy osiedlowe za pomocą wewnętrznych przestrzeni zieleni miejskiej i zlokalizowanych tam budynków oświaty. Dzielnicowy ośrodek handlowo-usługowy zlokalizowano w centralnej części planu. Wraz z naturalnym spadkiem wzgórza w kierunku rzeki Czechówki, zabudowa ulega rozdrobnieniu. W części położonej najbliżej centrum miasta, wzdłuż alei Tysiąclecia zlokalizowano funkcje usługowo-administracyjne, zgodnie z planowanym na tamten moment kierunkiem rozwoju strefy śródmiejskiej. 

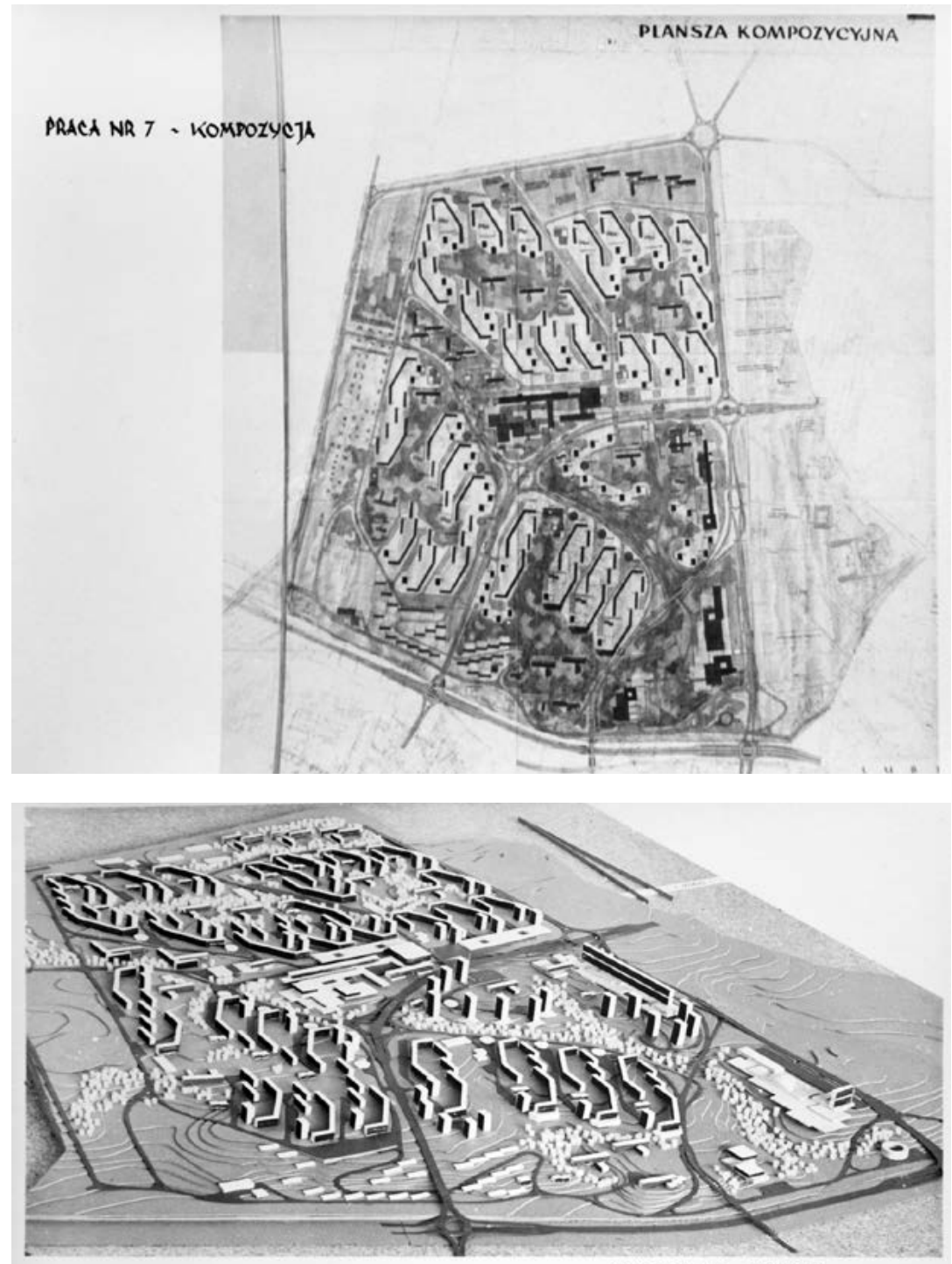

PRACA NR 7 - MAKETA
Ryc. 8. Plansza kompozycyjna pracy konkursowej nr 7 - III wyróżnienie.

Źródło: Archiwum Wydziału Planowania UM w Lublinie - zdjęcie: Michał Dmitruk

Ryc. 9. Model do pracy konkursowej nr 7 - III wyróżnienie.

Źródło: Archiwum Wydziału Planowania UM w Lublinie - zdjęcie: Michał Dmitruk

Ciekawą propozycją urbanistyczną był projekt zespołu nr 4, który nie został wyróżniony przez zespół sędziowski. Kształtuje on zabudowę w sposób bardzo plastyczny, swobodny i niespotykany w innych opracowaniach konkursowych. Jeden z autorów opracowania, Mirosław Załuski ${ }^{24}$ scharakteryzował układ zabudowy jako wachlarzowy. Plastyka układu urbanistycznego przypominać również może szkielet. Jest to przykład dość radykalnego podejścia do urbanistyki, gdyż wytworzony system niemalże równoległych do siebie, bardzo wysokich budynków, charakteryzuje się wysoką intensywnością zabudowy, nie tworząc jednocześnie przyjaznych przestrzeni międzyblokowych. Widać jednak na modelu stopniowe zmniejszanie skali budynków, w kierunku obrzeży każdego z trzech zespołów. Brak wspomnianych terenów zrekompensowany miał być dużą przestrzenią otwartą w centralnej części układu, zagospodarowaną przez tereny zielone, budynki mieszkalne i użyteczności publicznej o znacznie mniejszej skali. Duża strefa usługowo- handlowa, wraz z obiektami sportu i rekreacji umiejscowiona była w południowo-zachodniej stronie osiedla, najbliżej strefy śródmiejskiej. Propozycja zespołu nr 4 zdaje się nie uwzględniać planowanego układu drogowego, nie widać również propozycji powiązania funkcjonalnego z osiedlem istniejącej kolonii domów jednorodzinnych TOR. Plan rozmieszczenia budynków mieszkalnych osiedla zdaje się nie wynikać w sposób przejrzysty z naturalnej topografii terenu. 

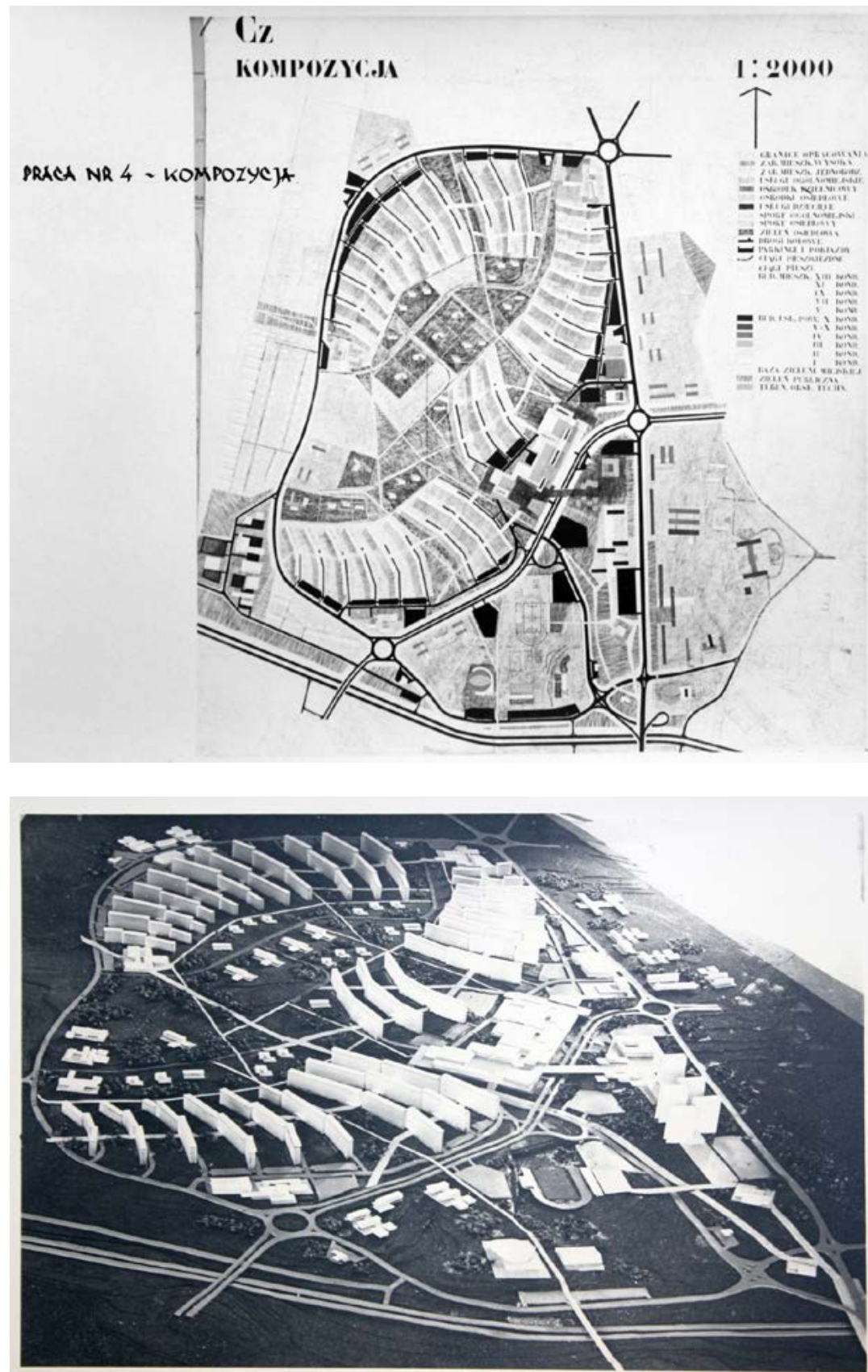

PRACA NR 4 - MAKIETA
Ryc. 10. Plansza kompozycyjna pracy konkursowej $\mathrm{nr} 4$

Źródło: Archiwum Wydziału Planowania UM w Lublinie - zdjęcie: Michał Dmitruk
Ryc. 11. Model do pracy konkursowej $\mathrm{nr} 4$

Źródło: Archiwum Wydziału Planowania UM w Lublinie - zdjęcie: Michał Dmitruk

\section{Plan miejscowy z 1969 roku}

Warunki określone w wytycznych konkursowych, jak i również złożone projekty posłużyły do opracowania na przełomie 1969-1970 roku Szczegółowego Planu Zagospodarowania Dzielnicy Czechów ${ }^{25}$. Przygotowaniem planu szczegółowego zajęła się krakowska pracownia Miastoprojekt, prowadzona przez zespół w składzie: mgr inż. arch. Zuzanna Perchał-Filar, mgr inż. arch. Leszek Filar i mgr inż. arch. Jerzy Pilitowski - czyli zespół 
nagrodzony w konkursie SARP I wyróżnieniem. Architekci byli również typowani jako projektanci docelowego założenia urbanistycznego Czechowa, jednak tak się ostatecznie nie stało. Plan szczegółowy przygotowano na bazie ogłoszonego w $1969^{26}$ Planu Ogólnego Zagospodarowania Lublina i zgodnie z wytycznymi Prezydium $\mathrm{MRN}^{27}$. Opracowanie doprecyzowywało założenia konkursowe, jednak zakresem dokładności nie wykraczało w sposób wyraźny poza warunki wcześniej określone w wytycznych SARP.

W planie założono identyczną strukturę wiekową mieszkańców, jaką przyjmowano w warunkach konkursowych. Przyjęto również zbieżne z konkursowymi współczynniki ilości obiektów o funkcji oświatowej. Docelową ilość osób zamieszkałych na opracowywanym terenie nieznacznie zwiększono z 40000 do 46000, co wynikało również z doprecyzowania granic dzielnicy.

Teren podzielono na 8 jednostek osiedlowych, oznaczonych odpowiednio literami A-H. Dla każdej z jednostek opracowano program funkcjonalny, zgodny z tabelą nr 1 . W opracowaniu planistycznym zawarto również dokładną inwentaryzację terenu, wraz z topografią, stanem zagospodarowania, jak i również charakterystykę powiązania funkcjonalnego i komunikacyjnego z pozostałymi strefami miejskimi. Ostatniemu zagadnieniu poświęcono wiele uwagi, chcąc powiązać w sposób właściwy nowoprojektowaną dzielnicę, z obiektami (obecnego) Uniwersytetu Medycznego, jak i również z planowaną śródmiejską strefą usługową, która rozwijać się miała począwszy od ul. Lubartowskiej, wzdłuż rzeki Czechówki. Istotnym elementem planu było ścisłe określenie głównych ulic obwodowych, dzielących w sposób zdefiniowany dzielnicę na mniejsze jednostki osiedleńcze.

Tabela 1. Program funkcjonalny dla poszczególnych osiedli w dzielnicy Czechów.

\begin{tabular}{|c|c|c|c|c|c|c|c|c|c|}
\hline \multicolumn{10}{|c|}{ PROGRAM DZIELNICY W GRANICACH MIEJSCOWEGO PLANU SZCZEGÓŁOWEGO } \\
\hline $\begin{array}{c}\text { Elem. } \\
\text { programu }\end{array}$ & $\begin{array}{l}\text { Jednost- } \\
\text { ka miary }\end{array}$ & $\begin{array}{l}\text { Jednost. } \\
\text { struktur. }\end{array}$ & $\begin{array}{l}\text { Jednost. } \\
\text { struktur. }\end{array}$ & $\begin{array}{l}\text { Jednost. } \\
\text { struktur. }\end{array}$ & $\begin{array}{l}\text { Jednost. } \\
\text { struktur. }\end{array}$ & & $\begin{array}{l}\text { Jednost. } \\
\text { struktur. }\end{array}$ & $\begin{array}{l}\text { Jednost. } \\
\text { struktur. }\end{array}$ & $\begin{array}{l}\text { Jednost. } \\
\text { struktur. }\end{array}$ \\
\hline & & A & B & C & $\mathrm{D}$ & $\mathrm{E}$ & $\mathrm{F}$ & G & $\mathrm{H}$ \\
\hline & osób & 7000 & 6300 & 7450 & b.d. & 6100 & 6550 & 6200 & 6400 \\
\hline $\begin{array}{l}\text { budown. } \\
\text { mieszkan. }\end{array}$ & $\begin{array}{l}\mathrm{m}^{2} \text { pow. } \\
\text { ogólnej. }\end{array}$ & 38,600 & 138,600 & 140,800 & b.d. & 134,200 & 140,800 & 136,400 & 140,800 \\
\hline
\end{tabular}

Usługi podstawowe skoncentrowane w ośrodku dzielnicowym:

\begin{tabular}{|cccccccccc} 
Handel & ha & 0,27 & 0,25 & 0,29 & b.d. & 0,24 & 0,26 & 0,24 & 0,25 \\
\hline Targowisko & ha & 0,30 & - & 0,30 & b.d. & - & - & - & - \\
\hline Rzemiosło & ha & 0,14 & 0,13 & 0,15 & b.d. & 0,13 & 0,14 & 0,13 & 0,13 \\
\hline $\begin{array}{c}\text { Gastronom. } \\
\text { Przychodnia } \\
\text { +apteka }\end{array}$ & ha & 0,05 & 0,04 & 0,06 & b.d. & 0,04 & 0,05 & 0,04 & 0,04 \\
\hline Poczta & ha & 0,24 & 0,24 & 0,24 & b.d. & 0,24 & 0,24 & 0,24 & 0,24 \\
\hline Administr. & ha & 0,023 & 0,022 & 0,025 & b.d. & 0,022 & 0,023 & 0,022 & 0,023 \\
\hline Klub osiedl. & ha & 0,08 & 0,08 & 0,08 & b.d. & 0,08 & 0,08 & 0,08 & 0,08 \\
\hline $\begin{array}{c}\text { Lokale } \\
\text { społ.-kult. }\end{array}$ & ha & 0,031 & 0,027 & 0,033 & b.d. & 0,026 & 0,029 & 0,027 & 0,027 \\
\hline Biblioteka & ha & 0,036 & 0,032 & 0,038 & b.d. & 0,031 & 0,033 & 0,032 & 0,033 \\
\hline Parkingi & ha & 0,54 & 0,54 & 0,54 & b.d. & 0,54 & 0,54 & 0,54 & 0,54 \\
\hline
\end{tabular}

Usługi Podstawowe rozproszone:

\begin{tabular}{|c|c|}
\hline $\begin{array}{c}\text { Pralnia, } \\
\text { warsztaty }\end{array}$ & 0,086 \\
\hline
\end{tabular}




\begin{tabular}{|c|c|c|c|c|c|c|c|c|c|}
\hline $\begin{array}{l}\text { Warsztaty } \\
\text { remontowe }\end{array}$ & ha & 0,15 & 0,15 & 0,15 & b.d. & 0,15 & 0,15 & 0,15 & 0,15 \\
\hline $\begin{array}{c}\text { Garaże } \\
\text { osiedlowe }\end{array}$ & ha & 0,40 & 0,40 & 0,40 & b.d. & 0,40 & 0,40 & 0,40 & 0,40 \\
\hline Parkingi & ha & 1,10 & 1,00 & 1,20 & b.d. & 0,80 & 1,10 & 0,80 & 1,00 \\
\hline \multicolumn{10}{|c|}{ Zieleń osiedlowa: } \\
\hline $\begin{array}{l}\text { Ogrody } \\
\text { osiedlowe }\end{array}$ & ha & 1,30 & 1,30 & 1,30 & b.d. & 1,30 & 1,30 & 1,30 & 1,30 \\
\hline $\begin{array}{c}\text { Zespoły } \\
\text { osiedlowe }\end{array}$ & ha & 1,23 & 1,10 & 1,30 & b.d. & 1,06 & 1,15 & 1,10 & 1,12 \\
\hline \multicolumn{10}{|c|}{ Oświata: } \\
\hline $\begin{array}{c}\text { Szkoła } \\
\text { podst. dla } \\
940 \text { uczniów }\end{array}$ & ha & 1,27 & 1,27 & 1,27 & b.d. & 1,27 & 1,27 & 1,27 & 1,27 \\
\hline $\begin{array}{c}\text { Przedszkole } \\
4 \text { oddz. } \\
0.48 \times 2\end{array}$ & ha & 0,96 & 0,96 & 0,96 & b.d. & 0,96 & 0,96 & 0,96 & 0,96 \\
\hline $\begin{array}{l}\text { Żłobek Typ I } \\
\text { dla } 55 \text { dzieci }\end{array}$ & ha & 0,34 & 0,34 & 0,34 & b.d. & 0,34 & 0,34 & 0,34 & 0,34 \\
\hline \multicolumn{10}{|c|}{ Mieszkalnictwo: } \\
\hline $\begin{array}{l}\text { Mieszkaln. } \\
\text { netto }\end{array}$ & ha & 12,53 & 11,72 & 19,58 & b.d. & 11,48 & 11,63 & 10,63 & 10,10 \\
\hline \multicolumn{10}{|c|}{ Zespoły usługowe: } \\
\hline $\begin{array}{l}\text { Zespoły usł. } \\
\text { netto }\end{array}$ & ha & 8,57 & 7,98 & 8,80 & b.d. & 7,72 & 8,17 & 7,77 & 8,00 \\
\hline
\end{tabular}

Opracowanie: Michał Dmitruk - za: Miejscowy Plan Szczegółowy dz. Czechów, 1969-1970, str. 5 i 6

W planie zwrócono również uwagę na zapewnienie dostępności do budynków dla osób niepełnosprawnych. Kładziono nacisk na realizację osiedlowych ogrodów i przestrzeni zielonych. Ważnym aspektem planu był zapis o dostosowaniu parametrów budownictwa wielorodzinnego do możliwości realizacji w systemie prefabrykacji, który to zaczął być stopniowo wdrażany w lubelskich osiedlach, w latach bezpośrednio poprzedzających powstanie opracowania. Określono również technologię realizacji budynków: Wielki Blok dla pierwszego etapu realizacji ${ }^{28}$, planowanego na lata 1971-1975, a w kolejnych etapach systemu W-70 (po powstaniu planowanej "fabryki domów"). Sugerowano aby projekty domów indywidualnych również realizowano w technologii uprzemysłowionej. Opracowano również wytyczne technologiczne, określające źródła zasilania osiedli w wodę, gaz i energię elektryczną. Nie ustalono natomiast wyraźnych zasad kompozycyjnych zabudowy ${ }^{29}$, dając przyszłym projektantom swobodę w tym zakresie.

\section{Realizacja}

Dnia 12-go listopada 1974 roku została powołana do życia "Spółdzielnia Mieszkaniowa Czechów w Lublinie", stając się głównym inwestorem, odpowiedzialnym za proces realizacji zabudowy osiedlowej. Tego samego dnia uchwalony został również statut i program działania Spółdzielni ${ }^{30}$. Równolegle rozpoczęto prace nad projektami urbanistycznymi i architektonicznymi dzielnicy. Laureaci I wyróżnienia w konkursie SARP i autorzy planu 
szczegółowego zagospodarowania Czechowa nie wzięli jednak udziału w pracach projektowych. Inaczej jak w przypadku konkursu ${ }^{31}$, każde z osiedli ostatecznie przeznaczono do zaprojektowania innemu zespołowi projektowemu. Pierwsze do realizacji zostało wytypowane osiedle oznaczone w planie jako B, nazwane imieniem Stanisława Moniuszki ${ }^{32}$. Za projekt tego osiedla, jak i również dwóch kolejnych (Wieniawskiego [C] i Lipińskiego [A]) odpowiedzialni byli współautorzy 3 pracy konkursowej - Rita i Tadeusz Nowakowscy. Byli to doświadczeni projektanci, odpowiedzialni za projekty zrealizowanych wcześniej w Lublinie dzielnic: Kalinowszczyzna i Tatary. Projekt kolejnego osiedla - Chopina $[\mathrm{E}]$ - opracowany został przez Bogdana Jezierskiego, autora m.in. osiedla im. Jana Zamoyskiego w Zamościu. Osiedle Szymanowskiego [F] i Paderewskiego [G] zaprojektowane zostało przez lubelskiego architekta Andrzeja Lisa. Ostatnie osiedle z okresu PRL, im. Karłowicza [H] zaprojektował Stanisław Machnik. Zabudowa osiedla D, nieujętego precyzyjnie w planie szczegółowym dzielnicy powstała dopiero po roku 1990, według realiów wolnorynkowych, bez całościowego konceptu.

Podstawowym założeniem projektu dzielnicy było: „uzyskanie jednolitego pod względem funkcjonalnym zespołu mieszkaniowego, jako integralnej części miasta w oparciu o trzy podstawowe funkcje projektowanej jednostki: mieszkalną, usługowa oraz spoteczną." ${ }^{\text {"3 }}$

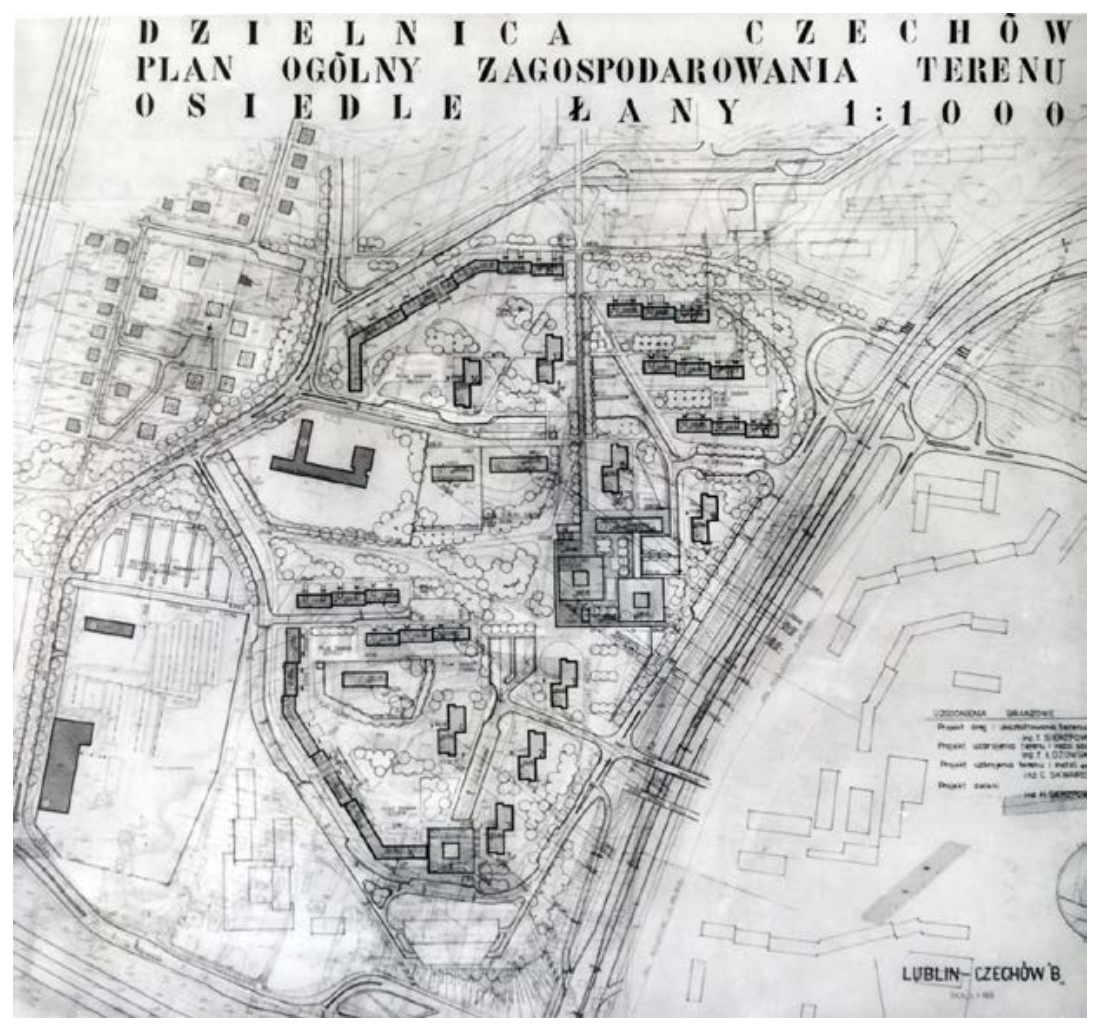

Ryc. 12. Rysunki projektowe os. im. St. Moniuszki na terenie lubelskiej dzielnicy Czechów.

Źródło: Dzięki uprzejmości Rity Nowakowskiej - zdjęcie: Michał Dmitruk

Zwrócono również uwagę na konieczność wykorzystania naturalnych walorów wynikających z bogatej rzeźby terenu. Na poszczególnych grzbietach lokalnych wzniesień, w ramach osiedla planowano mniejsze kolonie zabudowy, tworzące wnętrza urbanistyczne o skali sprzyjającej tworzeniu się więzi sąsiedzkich. Było to rozwiązanie zbieżne z proponowanym w opracowaniu konkursowym, gdzie podłużne bloki, ukształtowane w formy półksiężyców izolowały wnętrza kolonii od ruchu kołowego. W celu zróżnicowania typów zabudowy, jak i również sylwety osiedla wprowadzono stopniowanie wysokości podłużnych budynków, 11-sto kondygnacyjne punktowce, dominujące widokowo, jak i niskie klatkowce, uzupełniające kompozycję. W centralnym punkcie osiedli, na połączeniu osi komunikacji pieszej z kołową zaplanowano centra usługowe. Budynki oświatowe 
z kolei rozmieszczono zgodnie z planem zawartym w pracy nr 2, (I wyróżnienie), głównie z powodu iż część szkół zrealizowana została juz w 1966 roku (jeszcze przed powstaniem osiedla) w wyniku programu "Tysiąc szkót na tysiąclecie Państwa Polskiego" ${ }^{\prime 34}$ W pierwszym etapie realizacji, osiedle A przewidziane było dla 9177 mieszkańców, osiedle B dla 10605, a osiedle C dla 6020 osób (łącznie 25.802 os.).

Jako technologię realizacji zabudowy przyjęto systemy prefabrykowane: WB dla budynków punktowych i OWT -67 dla budynków w typie klatkowym. Osiedle C (Gaje - ob. Wieniawskiego) zamierzano potraktować w sposób indywidualny, ze względu na bliskość dzielnicowego centrum usługowego. Chciano mu nadać charakter wielkomiejski, przez zaplanowanie wysokiej, 16-sto kondygnacyjnej zabudowy (Ryc. 13). Tak sie ostatecznie nie stało a najwyższe budynki zrealizowano jako 11-sto kondygnacyjne ${ }^{35}$. Obsługę komunikacyjną osiedli zaproponowano na zasadzie ulic sięgaczowych, starając się maksymalnie wyprowadzić ruch kołowy z przestrzeni międzyblokowych. Główne tereny zielone planowano w najniższych nieckach osiedli i wąwozach, jednak najchętniej wykorzystywane są obecnie te zaplanowane najbliżej zabudowy, gdzie znajdują sie place zabaw i tereny wypoczynkowe.

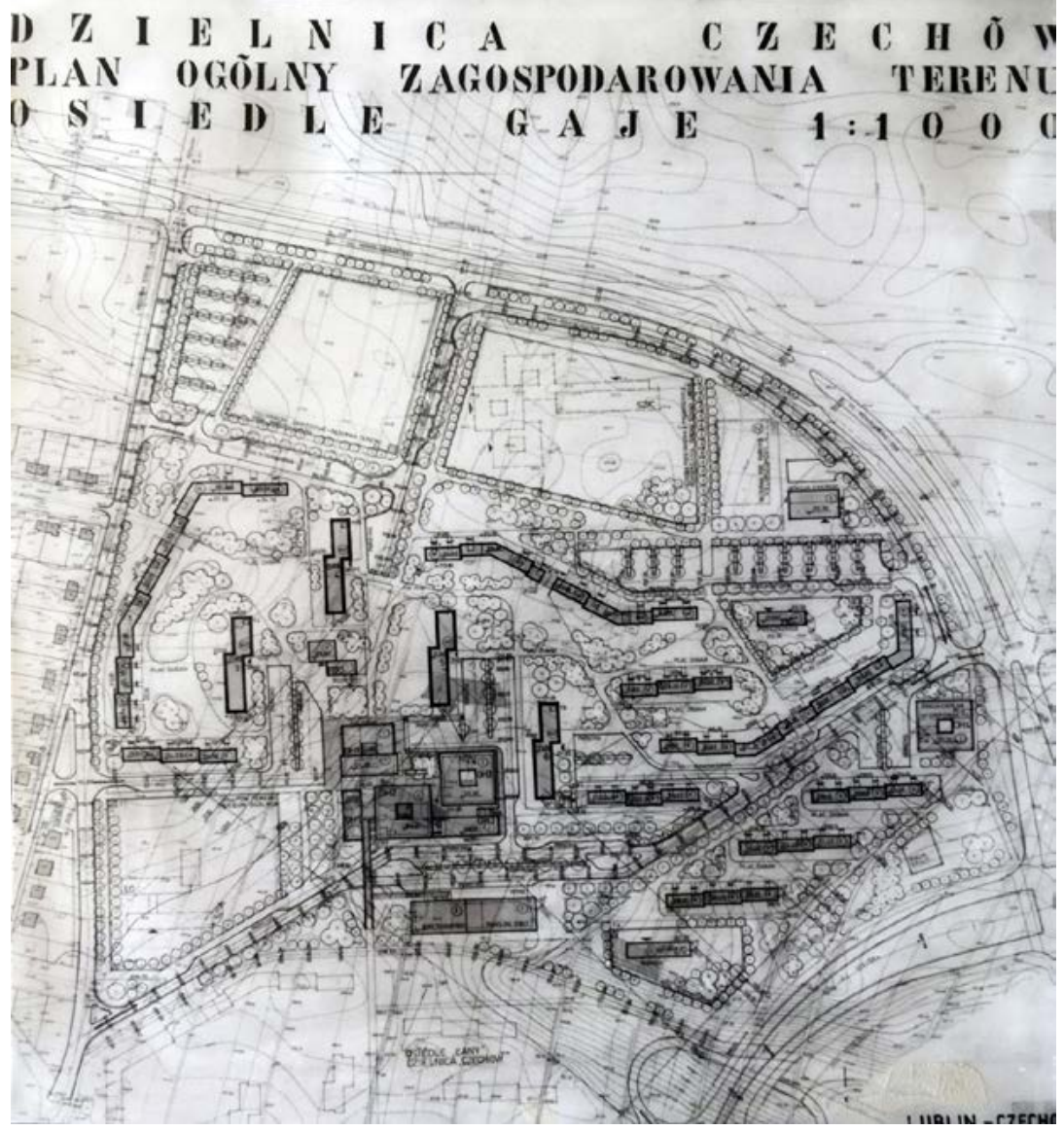

Ryc. 13. Rysunki projektowe os. im. H. Wieniawskiego na terenie lubelskiej dzielnicy Czechów.

Źródło: Dzięki uprzejmości Rity Nowakowskiej - zdjęcie: Michał Dmitruk

W projekcie przewidziano również precyzyjne dla każdego z osiedli współczynniki określające pow. zabudowy i kubaturę obiektów oświaty, handlowo-usługowych, gastronomicznych, ochrony zdrowia, kulturalnych,

34 Wałaszewski K., Tysiąc szkót na Tysiąclecie: Szkoły Tysiąclecia - architektura, propaganda, polityka, Księży Młyn Dom Wydawniczy, Łódź, 2018.

35 Ślad tych planów jednak pozostał, gdyż obecnie w przestrzeni osiedla D zezwolono na realizację 15-sto kondygnacyjnej zabudowy wielorodzinnej. 
warsztatów rzemieślniczych jak i również zbilansowano na potrzeby każdej z funkcji określoną liczbę miejsc postojowych. $^{36}$

25 listopada 1976 roku oddano do użytku pierwsze mieszkania na Czechowie, przy ul. Kiepury. Tego samego roku dokonano przydziału mieszkań zgodnie z założeniami polityki mieszkaniowej państwa: „mieszkanie dla dobrych pracowników uspołecznionych zakładów pracy"37. Za rozdział mieszkań odpowiedzialne były władze wojewódzkie. W roku 1975 na mieszkanie w dzielnicy Czechów oczekiwało: „1278 robotników, 1853 pracowników umystowych, 137 emerytów i rencistów,165 przedstawicieli studiującej i uczącej się młodzieży oraz 294 członków określanych mianem pozostali." ${ }^{38}$. W planie perspektywicznym zakładano budowę ok. 13000 mieszkań dla 39353 mieszkańców, o różnych klasach wielkościowych (od M1 do M7) na obszarze osiedli A-E. W Latach 80-tych Rozpoczęto budowę osiedli F-G, a od lat 90-tych, w warunkach wolnorynkowych, na terenie dzielnicy zrealizowano osiedle zabudowy jednorodzinnej „Choiny” jak i również realizuje się zabudowę osiedla D. Obecnie dzielnica posiada ok 40000 mieszkańców, jest więc zaludniona w stopniu miej intensywnym niż zakładały plany.

\section{Stan obecny - podsumowanie}

Osiedla znajdujące się w lubelskiej dzielnicy Czechów są poprawnie funkcjonującym i stale rozwijającym się elementem tkanki miejskiej. Wytyczne przygotowane na potrzeby konkursu SARP, zaprezentowane prace jak i również przygotowane później plany szczegółowe i projekty realizacyjne stanowiły ciągły proces klarowania się idei architektoniczno-urbanistycznej. Długi i konsekwentny cykl formułowania kształtu funkcjonalnego osiedla posłużył realizacji zamierzenia, które po ponad 40 latach od powstania sprawnie funkcjonuje i oferuje mieszkańcom atrakcyjne warunki do życia. Jest to zasługą skrupulatnej pracy komisji konkursowych, planistów miejskich, niezwykle doświadczonych projektantów jak i również administracji dzielnicy, która przez lata potrafiła zapewnić odpowiedni stan techniczny i użytkowy osiedli. Dzielnica obecnie rozwija się i przeobraża. Swobodny i przemyślany plan umożliwia dostosowanie zabudowy do zmieniających się potrzeb mieszkańców, z kolei bliskość obszaru śródmiejskiego, jak i ośrodków akademickich stanowi w dużej mierze o jego atrakcyjności. Rozwiązania planistyczne przyjęte w dzielnicy Czechów posłużyć mogą jako dobry przykład dla realizowanych współcześnie zespołów zabudowy mieszkaniowej, które częstokroć pozbawione są walorów oferowanych mieszkańcom już 40 lat temu.

\section{Bibliografia}

[1] Furgał E., Ogólny plan zagospodarowania przestrzennego m. Lublina z 1959 roku, [w:] Lubelska Pracownia Urbanistyczna 1955-2005, Lublin 2005.

[2] Majewski K., Dzielnica mieszkaniowa Czechów w Lublinie. Konkurs zamknięty SARP nr 424, Architektura, 10 (287)/1971.

[3] Pastuszko I., Plany urbanistyczne Lublina z lat pięćdziesiątych XX wieku : nowa ideologia czy przedwojenna kontynuacja, Rocznik Lubelski 43, 2017.

[4] Przesmycka N., Dzielnica Czechów w Lublinie - geneza układu urbanistycznego, [w:] TEKA Komisji Architektury, Urbanistyki i Studiów Krajobrazowych, Oddział Lubelski PAN, 3/2015.

[5] Śliwińska K., Socrealizm w PRL i NRD, Wydawnictwo Poznańskie, Poznań 2006.

[6] Wałaszewski K., Tysiąc szkót na Tysiąclecie: Szkoły Tysiąclecia - architektura, propaganda, polityka, Księży Młyn Dom Wydawniczy, Łódź 2018.

[7] Wójcikowski G., Wójcikowski W., Kronika 1944-1989, [w:] red. Kruszyńska J., Lublin. Dzieje miasta t. II: XIX i XX w., Lublin 2000 .

36 Zwrócić należy uwagę iż nie istniały ówcześnie normatywy określające rozmiar i ilość miejsc postojowych, więc planowano je jako place, które dziś odbiegają swoimi parametrami od wygodnie zaprojektowanych współczesnych parkingów.

37 Przesmycka N., Dzielnica Czechów w Lublinie - geneza układu urbanistycznego, [w:] TEKA Komisji Architektury, Urbanistyki i Studiów Krajobrazowych, Oddział Lubelski PAN, 3/2015 


\section{Akty prawne}

[1] Ustawa z dnia 21 lipca 1950 r. o 6-letnim planie rozwoju gospodarczego i budowy podstaw socjalizmu na lata $1950-1955$ Dz.U. z 1950 r. nr 37, poz. 344.

[2] Uchwała nr 364 Rady Ministrów z 20 sierpnia 1959 r. w sprawie zatwierdzenia normatywów projektowania dla budownictwa mieszkaniowego, MP 1959, nr 81, poz. 422.

[3] Uchwała nr 19/69 Prezydium MRN w Lublinie z dn. 27.08.1969 r.

\section{Inne opracowania i publikacje}

[1] Dokumentacja planu - opis do Miejscowego Planu Szczegółowego Zagospodarowania Przestrzennego Dzielnicy Czechów w Lublinie, 1969-1970.

[2] Opis Techniczny do Projektu Zagospodarowania Dzielnicy Czechów w Lublinie, 28.IV.1969.

[3] Stownik Geograficzny, t. I, Warszawa 1880.

[4] Warunki Konkursu Zamkniętego SARP, nr 424 na opracowanie koncepcji projektu planu szczegółowego zagospodarowania przestrzennego dzielnicy mieszkaniowej Czechów w Lublinie. 